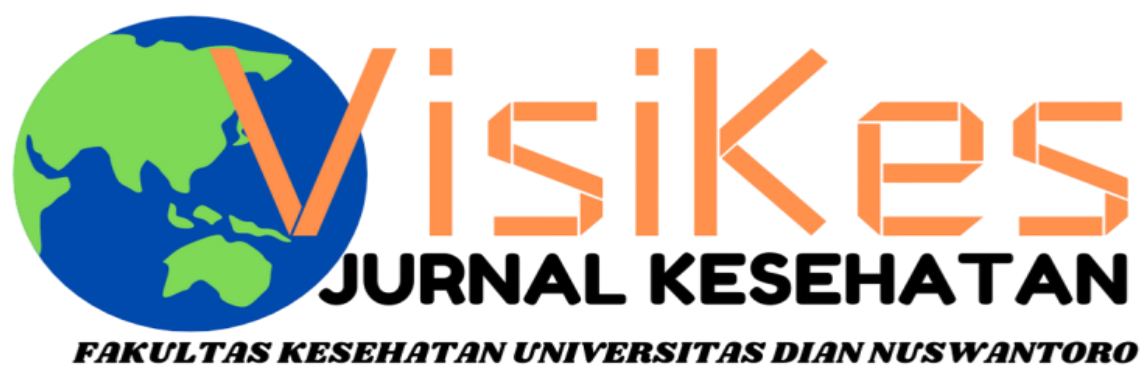

ISSN 1412-3746

FAKULTAS KESEHATAN UNIVERSITAS DIAN NUSWANTORO

Persepsi Mahasiswa Keperawatan Tentang Eskalasi Tenaga Perawat

Rendi Ariyanto Sinanto', Vivi Retno Intening ${ }^{2}$

Risiko kesehatan $\mathrm{Pb}$ dan $\mathrm{Hg}$ pada sayuran di desa Kopeng Kabupaten Semarang

Indira Casheila Anindityo ${ }^{1}$, Nur Endah Wahyuningsih ${ }^{2}$, Yusniar Hanani Darundiati ${ }^{3}$

Analisis Pelaksanaan Program Indonesia Sehat Dengan Pendekatan Keluarga (Pispk) Dalam Capaian Indeks Keluarga

Sehat Di Kabupaten Brebes Tahun 2020 Studi Pada Puskesmas Kluwut Kabupaten Brebes

Rizky Aprilianti Lestari ${ }^{1}$ dr. Antono Suryoputro ${ }^{1}$ Dr. dr. Apoina Kartini. M. Kes ${ }^{1}$

Disiplin Keselamatan dan Kesehatan Kerja melalui pemakaian alat pelindung diri di laboratorium kimia PT Sucofindo

Jakarta

Susan Endah Kartikasari ${ }^{1}$, Tatan Sukwika ${ }^{2}$

Perbedaan Pengetahuan Anemia dan Tablet Tambah Darah (TTD) Sebelum dan Sesudah Pendidikan Kesehatan Melalui

Media Video dan Aplikasi Quizlet

Devita Sari ${ }^{1}$, Gisely Vionalita ${ }^{2}$

Tingkat Pengetahuan Dan Perilaku Mahasiswi Mengenai Legalitas Dan Keamanan Kosmetik

Hani Sri Fitriani, Rizki Siti Nurfitria

Evaluasi Manajemen Dokumen Rekam Medis Di Filing Aktif Rumah Sakit Swasta Kabupaten Semarang

Bobby Anggara Laksana Putra ${ }^{1}$, Retno Astuti Setjaningsih ${ }^{2}$

Tingkat Pengetahuan Gizi Seimbang dan Profil Kesehatan Sopir Bus Antar Kota

Vilda Ana Veria Setyawati ${ }^{1}$, Bayu Yoni Setyo Nugroho ${ }^{1}$

Pengaruh Pengetahuan Dan Motivasi Kerja Terhadap Penerapan Early Warning Score System Di Rsup H Adam Malik Ita Riahna Pinem ${ }^{1}$, Zulfendri', Siti Saidah Nasution ${ }^{3}$

Analisis Penelusuran Masker Sebagai Protokol Kesehatan Saat Pandemi Covid-19 Di Indonesia: Studi Google Trends Ully Febra Kusuma ${ }^{1}$, Nurunnisa Arsyad ${ }^{2}$, Melissa Shalimar Lavinia ${ }^{3}$, Selvia Rahayu ${ }^{4}$, M. Khairul Kahfi , Rizma Adllia Syakurah ${ }^{6}$ Perilaku Hidup Bersih Dan Sehat (Phbs) Dengan Kejadian Sakit Pada Siswa Sekolah Dasar Di Kabupaten Banyumas Windri Lesmana Rubai ${ }^{1}$, Pramesthi Widya Hapsari', Katri Andirini Surijati ${ }^{3}$

Identifikasi Risiko Ganguan Muskuloskletal Pada Pekerja Percetakan Dengan Metode Nordic Body Map

Octavianus Hutapea ${ }^{1}$, Moch.Sahri', Rustam Basuki ${ }^{3}$

Literatur review: Implementasi Bauran Pemasaran 7P Terhadap Tingkat Kepuasan Pasien Di Rumah Sakit

Desi Natalia Marpaung ${ }^{1}$ Ernawaty $^{2}$ Diansanto Prayoga ${ }^{3}$ Syifa'ul Lailiyah $^{4}$

Kelengkapan Informasi Medis Untuk Mendukung Kodefikasi Penyakit Jantung Guna Mewujudkan Kualitas Data Informasi Medis Di Rumah Sakit Islam Sultan Agung Semarang

Dyah Ernawati ${ }^{1}$, Ratna Rifatul Ulya ${ }^{2}$, Arif Kurniadi ${ }^{3}$

Kajian Faktor Kendala Dokter Tidak Menggunakan Aplikasi Wifi Tb Di Kota Semarang

Arif Kurniadi', Evina Widianawati2, Dyah Ernawati ${ }^{3}$

Analisis Pelaksanaan Program Penanggulangan Tuberkulosis Paru Di Puskesmas Purwoyoso Kota Semarang

Nahari Ratu Cempaka Wilis ${ }^{1}$ Hardi Warsono ${ }^{2}$ M. Sakundarno Adi ${ }^{3}$

Hubungan Penggunaan Alat Pelindung Diri (Apd) Dengan Kadar Sgot Dan Sgpt Dalam Darah Pada Petani Padi

Iga Maliga, Rafi'ah

Faktor Risiko Kejadian Stunting Pada Balita di Wilayah Kerja Puskesmas Pandan Kabupaten Sintang

${ }^{1}$ Agustini Elisabet, ${ }^{2}$ Elvi Juliansyah

Peran Suami Dan Petugas Kesehatan Dengan Deteksi Dini Kanker Serviks

Christina Leasa, ${ }^{1}$ Mariene Wiwin Dolang

Analisis Penerapan Protokol Kesehatan terhadap Tingkat Kepatuhan Pada Pekerja informal Selama Pandemi Covid-19

MG Catur Yuantari ${ }^{1}$, Enny Rachmani ${ }^{2}$, Eti Rimawati ${ }^{1}$, Sri Handayani ${ }^{1}$, Edi Jaya Kusuma ${ }^{2}$

Peran Pengawas Minum Obat Dan Pendampingan Berobat Ulang Dengan Keberhasilan Pengobatan Tb Paru

Taswin $^{\left.1^{*}\right)}$, (zan $^{1)}$, Wahyuddin $^{1)}$, Dahmar ${ }^{1)}$

Faktor Determinan Sosial Dan Gambaran Kejadian Post Traumatic Syndrome Disorder (Ptsd) Pasca Banjir Di Dki Jakarta

Dan Bekasi Tahun 2020

Thresya Febrianti ${ }^{1}$, Nurfadhillah ${ }^{2}$, Mitha Nurhjanah ${ }^{3}$, Tiara Kautsa Aliefya ${ }^{4}$

Perbedaan Pola Makan Pada Balita Stunting Dan Tidak Stunting Di Kecamatan Teon Nila Serua (Tns) Kabupaten Maluku Tengah

Trixie Leunupun ${ }^{1}$, Ani Margawati' ${ }^{2}$ Annastasia Ediati ${ }^{3}$

Gambaran Pengelolaan Rekam Medis Rawat Inap Di Rsud Syekh Yusuf Kab. Gowa Tahun 2019

Zilfadhilah Arranury*, Surahmawati, Muhammad Rusmin, Tri Addya Karini, Dian Rezki Wijaya, Ranti Ekasari, Jihan Sulfitri

Analisis Risiko Kesehatan dalam Pemanfaatan Kemball Limbah Sludge Industri Makanan PT. X

Sri Slamet Mulyati ${ }^{1}$, Fajar Sihite ${ }^{2}$ 


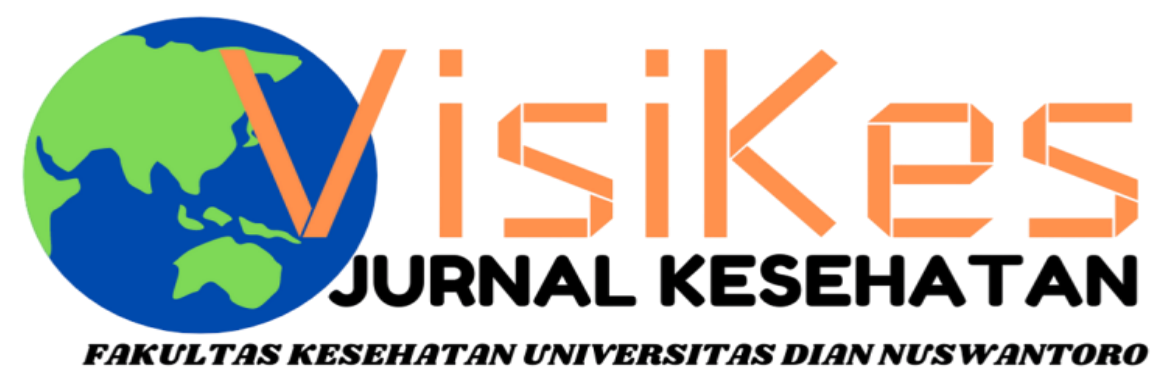

Volume 20, Nomor 1, April 2021

\section{Ketua Redaksi}

Dr. Drs. Slamet Isworo, M.Kes

\section{Penyunting}

Enny Rachmani, SKM, M.Kom, Ph.D

Fitria Wulandari, SKM, M.Kes

\section{Sekretariat}

Lice Sabata, SKM

Desain dan Layout

Puput Nur Fajri, SKM

\section{Alamat Redaksi}

Fakultas Kesehatan Universitas Dian Nuswantoro Jl. Nakula I No. 5-11 Semarang Telp/fax. (024) 3549948

email : visikes@fkes.dinus.ac.id

website $\quad$ : http://publikasi.dinus.ac.id/index.php/visikes/index

VisiKes diterbitkan mulai Maret 2002

Oleh Fakultas Kesehatan Universitas Dian Nuswantoro 


\title{
Analisis Penelusuran Masker Sebagai Protokol Kesehatan Saat Pandemi Covid-19 Di Indonesia: Studi Google Trends
}

\author{
Ully Febra Kusuma ${ }^{1}$, Nurunnisa Arsyad ${ }^{2}$, Melissa Shalimar Lavinia ${ }^{3}$, Selvia Rahayu ${ }^{4}$, \\ M. Khairul Kahfi ${ }^{5}$, Rizma Adllia Syakurah ${ }^{6}$ \\ 1. Medical Doctor Profession Education, Faculty of Medicine, Universitas Sriwijaya \\ 2. Faculty of Public Health, Universitas Sriwijaya \\ Email: rizma.syakurah@gmail.com
}

\begin{abstract}
Abstrak
Medical masks are also used by people at risk who are indicated to need them. The supply of medical masks is limited, the general public is encouraged to use non-medical masks or cloth masks. This article will discuss the comparison of search results for sensi masks, cloth masks and N-95 masks using google trend analysis. This research method is a qualitative and quantitative study using time series data with quantitative analysis, time-lag correlation is used to assess whether an increase in GT data is correlated with an increase in COVID-19 cases. Data from google trends regarding keywords related to one of the preventive measures for COVID-19, namely masks such as "sensi masks", "cloth masks" and "N-95 masks". Each search interest usually reaches a peak depending on the situation and conditions that occur at that time. The keyword search for " $\mathrm{N}$-95 masks" experienced a peak when 2 Indonesians were confirmed positive for COVID-19, namely on March 2, 2020 and the day after that the keyword "sensi mask" also experienced the highest peak of searches. The keyword search for "cloth masks" peaked on March 6, 2020, when the price of sensi masks began to rise. The results of the keyword correlation test for "sensi mask", "cloth mask" and "N-95 mask" show that the keyword search results on Google trended a decline in line with the increase in COVID-19 cases in Indonesia. Public interest in tracing increased at the beginning of COVID-19 entering Indonesia. However, the interest in this search continues to decline and is inversely proportional to the increase in the incidence of COVID-19 cases in Indonesia.
\end{abstract}

Keywords: COVID-19, sensi masks, medical masks, cloth masks, N-95 masks, Google trends

\section{PENDAHULUAN}

World Health Organization (WHO) memberikan panduan protokol kesehatan dalam pencegahan penularan COVID-19. Protokol kesehatan tersebut, yang terutama meliputi mencuci tangan, memakai masker dan menjaga jarak dengan orang lain minimal 1 meter. Penggunaan masker merupakan bagian dari rangkaian komprehensif langkah pencegahan dan pengendalian yang dapat membatasi penyebaran penyakit-penyakit virus saluran pernapasan tertentu, termasuk COVID-19. Masker dapat digunakan baik untuk melindungi orang yang sehat (dipakai untuk melindungi diri sendiri saat berkontak dengan orang yang terinfeksi) atau untuk mengendalikan sumber (dipakai oleh orang yang terinfeksi untuk mencegah penularan lebih lanjut). ${ }^{1}$

Tenaga kesehatan diharuskan untuk memakai masker bedah/masker medis atau masker N-95. Tenaga kesehatan adalah semua orang yang terlibat terutama dalam tindakan-tindakan yang tujuan utamanya adalah meningkatkan kesehatan. Contohnya, tenaga perawat dan bidan, dokter, petugas kebersihan, staf lain yang bekerja di fasilitas pelayanan kesehatan, tenaga bidang sosial, tenaga kesehatan komunitas, dll. Masker medis merupakan bagian dari APD, yang 
melindungi bagian mulut dan hidung dari droplet dan kontak virus COVID-19. Beberapa penelitian menunjukkan bahwa efektivitas dari penggunaan masker medis dibandingkan dengan masker N-95 relatif sama, tidak ada perbedaan yang signifikan, sebagai bentuk proteksi dari infeksi COVID-19. ${ }^{1}$ Metaanalisis kajian-kajian literatur sistematis melaporkan tidak adanya kaitan risiko lebih rendah yang secara statistik signifikan mengenai hasil rawat penyakit saluran pernapasan klinis atau infeksi influenza atau virus yang terkonfirmasi laboratorium pada penggunaan respirator N95 dibandingkan dengan penggunaan masker medis. Akan tetapi, pada tempat perawatan pasien COVID-19 di mana AGP dilakukan (misalnya, unit perawatan intensif dan semiintensif COVID-19), WHO merekomendasikan agar tenaga kesehatan mengenakan respirator (standar N95 atau FFP2 atau FFP3, atau yang setara). 1,2

Penggunaan masker medis di masyarakat dapat mengalihkan sumber daya yang penting ini dari tenaga kesehatan dan orang-orang yang paling membutuhkannya. Di tempat-tempat di mana terjadi kekurangan persediaan masker medis, masker medis harus dikhususkan bagi tenaga kesehatan dan orang-orang berisiko yang terindikasi memerlukannya. Oleh karena itu, masyarakat umum dianjurkan untuk menggunakan masker non medis atau yang biasa disebut dengan masker kain. ${ }^{1}$ Masker kain yang direkomendasikan adalah masker yang memiliki 3 lapisan kain. Lapisan pertama adalah lapisan kain hidrofilik seperti katun, kemudian dilapisi oleh kain yang bisa mendukung viltrasi lebih optimal. Pada lapisan kedua ini bisa juga menggunakan katun atau polyester. Lapisan ketiga atau bagian masker paling luar menggunakan lapisan hidrofobik atau bersifat anti air seperti terbuat dari polypropylene. Masker kain dapat dicuci dan digunakan kembali. Oleh karena itu pencucian dan penyimpanannya harus tepat, ${ }^{3}$ Masker nonmedis dapat digunakan secara ad hoc, saat masyarakat beraktivitas di luar rumah. Selain itu, penggunaan masker nonmedis harus selalu dibarengi dengan protokol kesehatan lainnya, seperti sering mencuci tangan dan penjagaan jarak fisik. ${ }^{1}$ Pada artikel ini akan membahas perbandingan penggunaan masker bedah/masker medis, masker kain dan masker $\mathrm{N}-95$ dengan menggunakan analisis Google Trend (GT). ${ }^{1}$

\section{METODE}

Penelitian ini merupakan penelitian kualitatif dan kuantitatif dengan menggunakan data time series mulai dari 2 Maret 2020 hingga 2 September 2020. Kami menggunakan laporan resmi harian kasus baru COVID-19 dari (https://bnpbinaCOVID19.hub.arcgis.com/) sebagai situs resmi Satgas Percepatan Penanggulangan COVID-19 di Indonesia oleh Badan Nasional Penanggulangan Bencana / BNPB. Kata kunci terkait minat pencarian tentang masker kami gunakan untuk dibandingkan dengan angka kejadian COVID-19 di Indonesia. Masker sebagai salah satu upaya pencegahan penyebaran COVID-19 yang kami jadikan sebagai kata unci pencarian dalam penelitian adalah adalah masker sensi, masker kain dan masker N9. Google Trends menyajikan relative 
search volume (RSV) dan datanya disesuaikan dengan waktu dan lokasi, sehingga perbandingan antar kueri dapat lebih mudah. Hasilnya dapat diunduh dalam format Common Separated Values (CSV), yang ditampilkan dalam skala dari 100 untuk perhatian tertinggi pada kata kunci hingga 0 untuk perhatian terendah pada Kata kunci. Data dari GT kemudian dibandingkan dengan jumlah kasus baru COVID-19 harian. Rata-rata pergerakan dengan interval tiga hari dari jumlah kasus baru harian COVID-19 dan data GT diterapkan ke grafik untuk menilai pola tren pencarian selama pengamatan periode rvation. Metode rata-rata bergerak ini digunakan untuk memfasilitasi perbandingan tren antar dataset. analisis kualitatif yang digunakan di setiap lonjakan / puncak minat penelusuran. Untuk analisis kuantitatif, korelasi time-lag digunakan untuk menilai apakah peningkatan data GT berkorelasi dengan peningkatan kasus COVID-19 berikut, seperti yang diterapkan sebelumnya pada penelitian lain.

\section{HASIL DAN PEMBAHASAN}

Pada gambar 1, Hasil analisis data menunjukkan deret waktu jumlah kasus baru COVID-19 di Indonesia divisualisasikan dengan data GT mengenai minat pencarian kata kunci terkait masker periode 2 Maret - 2 September 2020. Terdapat tiga puncak untuk "masker kain", empat puncak untuk "masker sensi" dan empat puncak untuk "masker N95".

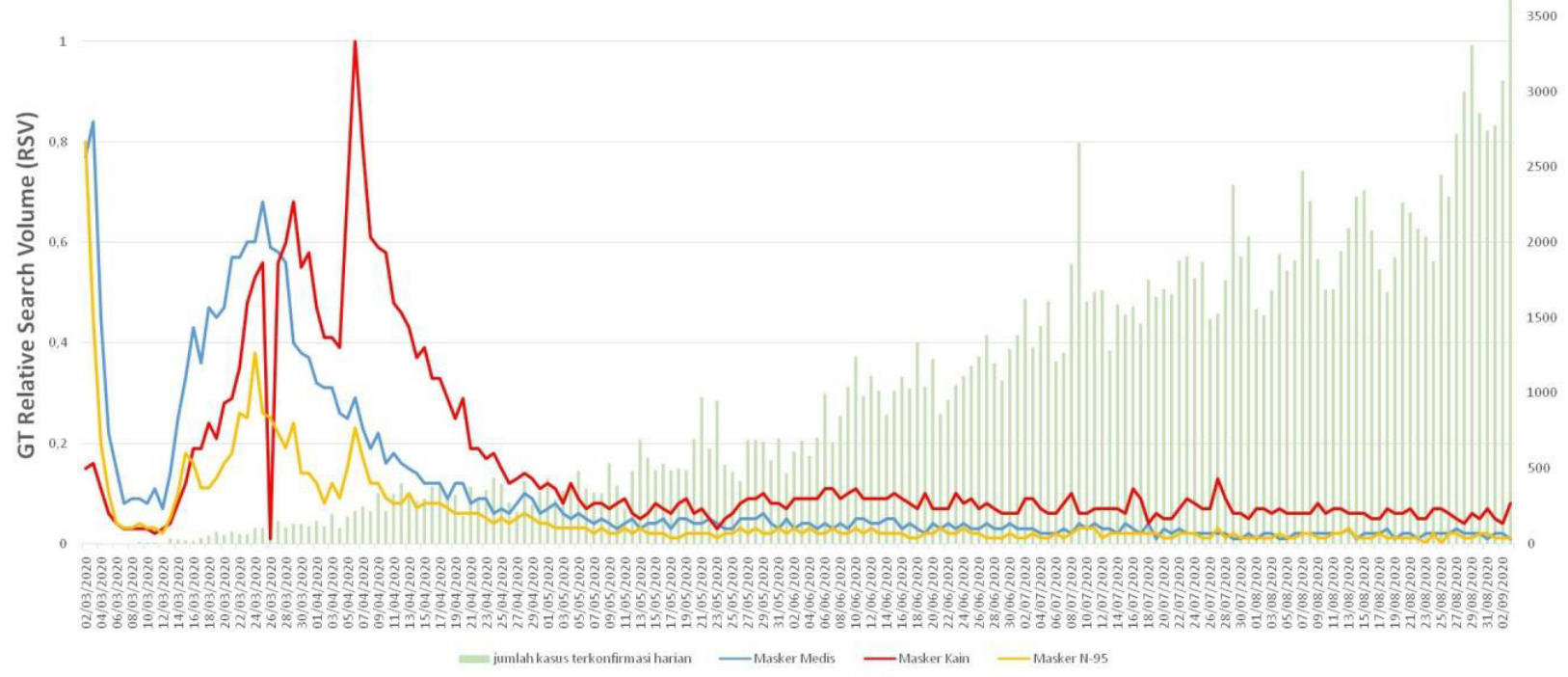

Gambar 1. Perbandingan minat pencarian harian kata kunci masker sensi, masker kain, masker N95 di Indonesia periode 2 Maret - 2 September 2020.

Kata kunci pertama yang meningkatkan minat pencarian adalah "masker sensi". Pada tanggal 3 Maret 2020 terjadi peningkatan minat pencarian "masker sensi" seiring dengan semakin meningkatnya jumlah kasus masyarakat mulai mempersiapkan segala 
kebutuhan alat pelindung diri terutama penggunaan masker sensi ini karena belum ada anjuran dari pemerintah ataupun WHO untuk menggunakan masker yang jenis lainnya. ${ }^{11}$ pada penelitian sebelumnya menunjukkan kata kunci masker mengalami peningkatan selama masa pandemi. ${ }^{12}$

Minat penelusuran untuk "masker sensi" mencapai puncak pertama pada 3 Maret 2020 setelah pengumuman dari presiden bahwa sudah terdapat kasus COVID 19 pada tanggal 2 Meret 2020. Sejak pengumuman tersebut harga masker mulai meningkat terutama masker medis dengan merek sensi, hal ini karena sebelum COVID masuk di Indonesia. Pada bulan Januari pemerintah mengekspor masker medis ini ke china yang merupakan Negara asal munculnya COVID-19 pertama kali pada Desember 2019. Harga masker ini melonjak naik juga pengaruh dari berbagai penjual yang sengaja menaikkan harga masker 5 kali lipat dari harga normal sebelumnya. ${ }^{11}$

Puncak kedua terjadi pada tanggal 16 Maret 2020 dan puncak ketiga pada 21 Maret 2020 terjadi penurunan. Kemudian puncak keempat pada 25 Maret 2020 di puncak ini terjadi sedikit peningkatan akan tetapi tidak melebihi lebih puncak pertama. Awal muncul COVID 19, Menurut WHO penggunaan masker hanya untuk orang yang sakit saja, dan pengaruh menurunnya pencariaan masker ini disebabkan oleh mahalnya harga masker, serta beberapa masyarakat sudah mempersiapkan dari jauh hari mengenai pembelian masker medis atau sensi. Penggunaan masker bedah hanya disarankan bagi tenaga kesehatan yang bertugas difasilitas kesehatan, dan masyarakat umum yang sedang sakit untuk mencegah terjadinya penularan kuman kepada orang lain. Masker ini hanya digunakan sekali pakai. Kebijakan penggunaan masker disampaikan oleh $\mathrm{dr}$. Mike Ryan, Pakar darurat WHO pada konferensi pers, dilansir dari Channel News Asia, namun adanya kebijakan baru dari WHO tersebut, Pemerintah Indonesia mendorong agar seluruh masyarakat menggunakan masker apabila akan keluar dari rumah. ${ }^{9}$ Minat pencarian terkait "Masker Sensi" mencapai puncak hanya bulan Maret kasus COVID-19 di Indonesia semakin lama pencarian masker ini semakin menurun.

Kata kunci "masker kain" meningkat pada tanggal 2 Maret 2020. Dan dihari yang sama Presiden Joko Widodo dan Menteri Kesehatan Terawan Agus Putranto mengumumkan kasus positif virus corona COVID-19 pertama di Indonesia pada Senin 2 Maret 2020. Saat itu, Presiden Joko Widodo (Jokowi) mengumumkan ada dua orang Indonesia positif terjangkit COVID-19 yaitu perempuan berusia 31 tahun dan ibu berusia 64 tahun. Banyak masyarakat yang menjadi ketakutan, hingga memborong masker di apotik atau pasar swalayan. menjadikan masker semakin langka dan mahal di Indonesia. $^{7}$

Peningkatan berikutnya pada kata kunci "masker kain" terjadi pada tanggal 25 Maret 2020. Dikarenakan warga kesulitan mendapatkan masker kesehatan, sehingga meningkatnya pembelian masker kain disejumlah daerah di Indonesia, seperti di 
Jakarta dan Pariaman. ${ }^{5,6}$ Padahari yang sama Kepala Dinas Kesehatan Kota Pariaman Syahrul mengatakan penggunaan masker kain atau sejenisnya dapat digunakan untuk meminimalisasi terserang COVID-19. ${ }^{8}$

Peningkatan tajam mengenai kata kunci “masker kain" tejadi pada 6 Maret 2020. Imbauan memakai masker kain menjadi pilihan terbaik di tengah semakin mahal dan langkanya masker bedah dan N95 di pasaran. Imbauan memakai masker hanya untuk yang sakit atau terinfeksi virus corona sudah tak berlaku lagi. World Health Organizations (WHO) mengubah kebijakan dan kini mendukung penggunaan masker untuk semua orang di tengah penyebaran pandemi COVID19. Minggu 5 Maret 2020 pemerintah meminta seluruh masyarakat menggunakan masker. Presiden Joko Widodo pun mengatakan hal serupa "Masker sekarang betul-betul disiapkan dan berikan kepada masyarakat. Kami ingin agar setiap warga yang harus keluar rumah wajib memakai masker". ${ }^{10}$

Selain itu, minat penelurusan mengenai kata kunci "masker N95" puncak pertama terjadi pada 28 Januari 2020. Pada hari yang sama pemerintah Indonesia mengirimkan 5 ribu dari 10 ribu masker N95 kepada Pemerintah China untuk pencegahan tersebarnya wabah virus corona. Masker akan didistribusikan ke masyarakat dan mahasiswa Indonesia sebagai perlindungan terhadap virus corona sampai situasi krisis mereda. ${ }^{11}$

Puncak selanjutnya mengenai kata kunci “masker N95" terjadi pada 2 Maret 2020. Pada hari yang sama masker di toko alat-alat kesehatan di Pasar Pramuka, Jakarta Timur, melambung akibat ada warga Indonesia yang tertular virus korona (COVID-19). Permintaan masker dari masyarakat terus naik. Masker N95 juga naik signifikan hingga Rp1,3 juta per boks. Ketika belum ada isu wabah korona, masker N95 biasa dijual Rp200 ribu per boks. ${ }^{9}$ Harga masker N95 pun melambung naik. Dalam kondisi normal, harga masker jenis N95 hanya $\mathrm{Rp} 200.000$ per kotak berisi 20 lembar atau setara Rp 10.000 per lembar. Tapi beberapa waktu lalu harga masker jenis ini sempat melambung hingga Rp 1,3 juta per kotak. $^{13}$

Puncak ketiga untuk penulusuran "masker n95" terjadi pada tanggal 16 maret 2020 namun pada puncak kedua ini sudah terjadi penurunan angka pencarian masker n95 tidak setinggi puncak pertama. Kemudian puncak keempat terjadi pada tanggal 24 maret 2020 yang mana agak sedikit meningkat dari pada puncak kedua. Pada tanggal 6 april angka pencarian masker n95 semakin menurun hingga 5 September 2020. Hal ini berhubungan dengan peningkatan kasus setiap hari dan penggunaan masker ini lebih dikhususkan oleh tenaga medis. ${ }^{14}$ Sebuah analisis baru terhadap 172 studi mengonfirmasi mengenai apa yang pernah dikatakan para ilmuwan selama ini yakni N95 beserta masker respirator lain jauh lebih unggul dalam melindungi tenaga medis dari virus corona. Hasil penelitian yang diterbitkan The Lancet tersebut menegaskan bahwa Organisasi Kesehatan Dunia atau WHO beserta Pusat Pengendalian dan Pencegahan Penyakit (CDC) seharusnya merekomendasikan pekerja medis seperti 
perawat dan mereka yang di UGD mengenakan masker N95, bukan sekedar masker biasa. Penggunaan masker Respirator N95 dapat sekali pakai namun dapat digunakan berulang dengan beberapa persyaratan pada kondisi darurat. Respirator N95 yang digunakan berulang harus dipastikan bersih, dan tidak basah. Penggunaan pelindung wajah, masker bedah setelah respirator N95 atau cara mekanik lainnya akan membantu mengurangi kontaminasi. Respirator N95 yang telah digunakan untuk tindakan yang menimbulkan aerosol sebaiknya tidak digunakan berulang. ${ }^{13}$

Setelah WHO menganjurkan untuk terutama masker kain maka minat pencarian untuk masker medis semakin menurun mulai dari 2 April hingga 2 September 2020. Provinsi dengan minat pencarian masker sensi yang menempati posisi pertama adalah DKI Jakarta, kemudian diikuti oleh Banten, Bangka Belitung, Jawa Timur dan Sumatera Utara (Tabel 1). Provinsi dengan minat pencarian masker kain terbanyak adalah Provinsi Maluku, diikuti oleh Kalimantan Utara, NTB, Bengkulu dan Kalimantan Selatan. Sedangkan pencarian masker N-95 provinsi Maluku Utara menempati urutan pertama, kemudian diikuti oleh Papua, Sulawesi Tengah, Sulawesi Selatan, dan Gorontalo. semua masyarakat menggunakan masker

Tabel 1. Provinsi dengan Kata Kunci Minat Tertinggi Terkait Penggunaan Masker

\begin{tabular}{|c|c|c|}
\hline Sensi Masker & Masker Kain & Masker N-95 \\
\hline DKI Jakarta & Maluku & Maluku Utara \\
\hline Banten & Kalimantan Utara & Papua \\
\hline Bangka Belitung & Nusa Tenggara Barat & Sulawesi Tengah \\
\hline Jawa Timur & Bengkulu & Sulawesi Selatan \\
\hline Sumatera Utara & Kalimantan Selatan & Gorontalo \\
\hline
\end{tabular}

Tabel 2. Permintaan minat pencarian dengan kata kunci yang terkait dengan penggunaan masker di Indonesia

\begin{tabular}{|c|c|c|}
\hline Sensi Masker & Masker Kain & Masker N-95 \\
\hline "masker sensi distributor" & "masker kain scuba" & "masker n-95 8210" \\
\hline "distributor masker" & "kain scuba" & "masker bedah \\
\hline "masker murah" & "masker scuba" & "harga masker 3m n-95" \\
\hline "masker sensi surabaya" & "masker kain corona" & "masker kn-95" \\
\hline "grosir masker sensi" & "cara buat masker" & "masker n-95 1860" \\
\hline "sensi masker" & "ukuran masker kain" & "masker scuba" \\
\hline "agen masker sensi" & "model masker kain" & "masker n-95 surabaya" \\
\hline "toko masker sensi" & "cara buat masker kain" & "masker 95" \\
\hline "sensi masker earloop" & "jenis masker" & "masker n-95 bisa dicuci" \\
\hline "masker earloop sensi" & "bikin masker kain" & "bahan masker 95" \\
\hline
\end{tabular}

Query terkait kata kunci "Masker Sensi", Masker Kain" dan "Masker N95" dapat dilihat pada tabel 2. Query terkait dapat menggambarkan pola kebiasaan pencarian di Indonesia. Berdasarkan data GT, untuk
"Masker Sensi" penulusuran nya lebih banyak mengenai distributor masker sensi serta harga masker nya murah atau tidak karena berhubung masker tersebut terjadi kenaikan harga. Untuk "Masker Kain" penelusuran 
paling banyak adalah masker kain merk scuba karena masker tersebut murah dan nyaman digunakan namun masker ini tidak terlalu efektif dalam mencegah penularan COVID 19 sehingga saat menggunakan masker tersebut harus tetap ikuti protokol kesehatan seperti tetap jaga jarak dan cuci tangan. ${ }^{15}$ Sedangkan untuk pencarian "masker N95" lebih megarah ke seperti apa gambaran masker n-95 yang tingkat proteksinya lebih tinggi dan bisa di dekontaminasi ulang sehingga dapat dipakai beberapa kali. ${ }^{16}$

Tabel 3. Hasil Korelasi time-lag Pearson antara keyword yang terkait dengan jenis-jenis masker dalam kasus harian GT-RSV dan COVID-19 di Indonesia

\begin{tabular}{|c|c|c|c|c|c|c|c|}
\hline \multirow[t]{2}{*}{ Search Term } & \multicolumn{7}{|c|}{ Days } \\
\hline & Lag-3 & Lag-2 & Lag-1 & Lag 0 & $\mathrm{Lag}+1$ & $\mathrm{Lag}+2$ & $\mathrm{Lag}+3$ \\
\hline Sensi Masker & $-0,529^{\star *}$ & $-0,533^{\star *}$ & $-0,538^{\star \star}$ & $-0,544^{\star *}$ & $-0,550^{\star *}$ & $-0,550^{\star *}$ & $-0,551^{* *}$ \\
\hline Masker Kain & $-0,424^{\star \star}$ & $-0,430^{* \star}$ & $-0,441^{\star \star}$ & $-0,448^{\star \star}$ & $-0,454^{\star \star}$ & $-0,457^{\star \star}$ & $-0,455^{\star \star}$ \\
\hline Masker N-95 & $-0,441^{\star \star}$ & $-0,446^{\star \star}$ & $-0,450^{\star \star}$ & $-0,455^{\star \star}$ & $-0,459^{\star \star}$ & $-0,462^{\star *}$ & $-0,463^{\star \star}$ \\
\hline \multicolumn{4}{|c|}{${ }^{*}$ Signifikan dengan $\mathrm{P} \leq 0.01$} & \multicolumn{3}{|c|}{$\begin{array}{l}\text { Koefesien Korelasi Pearson } \\
\begin{array}{|l|l|l|l|}0,0,21 & 0,40 & 0,4\end{array} \\
\end{array}$} & \\
\hline
\end{tabular}

Hasil korelasi Pearson antara data GTRSV minat pencarian keyword dan data kasus COVID-19 ditunjukkan pada tabel 3 di atas. Hasil analisis data menunjukkan bahwa keyword "Sensi Masker" mempunyai nilai korelasi negatif yang sangat kuat $(r=-0,544)$ dibandingkan dengan keyword "Masker N-95" $(r=-0,459)$ dan "Masker Kain" $(r=-0,454)$. Hal ini menunjukkan bahwa ketertarikan seseorang untuk mencari data terkait "sensi masker", "masker kain" dan "masker N-95" di Indonesia semakin kecil seiring dengan pertambahan jumlah kasus COVID-19. Jika dilihat dari periode time-lag ditemukan bahwa terjadi penurunan aktivitas pencarian keyword tersebut melalui GT RSV pada tiga hari sebelumnya hingga permulaan kasus COVID19 yang baru dikonfirmasi di Indonesia sampai dengan tiga hari kedepannya. Minat pencarian seseorang yang tinggi awalnya dapat disebabkan karena terjadi infodemik dan munculnya disinformasi dan misinformasi mengenai COVID-19 di Indonesia. Banjir informasi di media sosial ini dapat mempengaruhi kondisi emosional seseorang karena persepsi keparahan COVID-19, sehingga minat pencarian masyarakat meningkat saat awal-awal kasus diumumkan, dan menurun seiring edukasi dan penyebaran informasi yang valid dari pemerintah.

Hasil korelasi time-lag pearson antara keyword "Sensi Masker" dan kasus harian COVID-19 pada lima provinsi teratas dengan minat penelusuran tertinggi ditunjukkan pada Gambar 1. Gradasi warna pada peta menunjukkan tingkat minat, gradasi yang lebih gelap menunjukkan tingkat minat yang lebih rendah. 


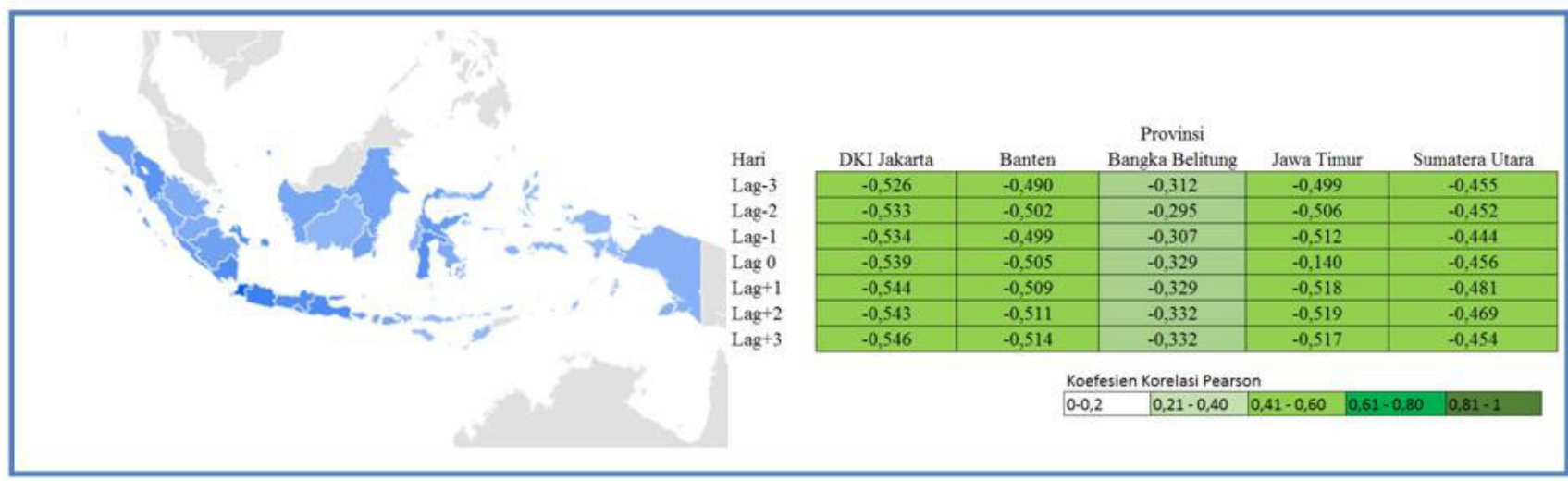

Gambar 1. Hasil korelasi time-lag pearson antara keyword "Sensi Masker" dan kasus harian COVID-19 pada lima provinsi teratas dengan minat penelusuran tertinggi.

*Signifikan dengan $\mathrm{P} \leq 0,05$

**Signifikan dengan $\mathrm{P} \leq 0,01$

Di Provinsi Bangka Belitung secara signifikan menunjukkan korelasi negatif yang rendah. Temuan ini mencerminkan bahwa terjadi sedikit peningkatan minat aktivitas googling pada satu hingga tiga hari sebelum, sesudah dan pada hari peningkatan kasus COVID-19 dibandingkan empat provinsi teratas lainnya. Sedangkan pada empat provinsi lainnya yakni DKI Jakarta, Banten, Jawa Timur dan Sumatera Utara memiliki korelasi negatif sedang yang menunjukkan bahwa minat aktivitas googling pada satu hingga tiga hari sebelum, sesudah dan pada hari COVID-19 lebih rendah daripada daerah Bangka Belitung.

Hasil korelasi time-lag pearson antara keyword "Masker Kain" dan kasus harian COVID-19 pada lima provinsi teratas dengan minat penelusuran tertinggi ditunjukkan pada Gambar 2. Gradasi warna pada peta menunjukkan tingkat minat, gradasi yang lebih gelap menunjukkan tingkat minat yang lebih rendah.

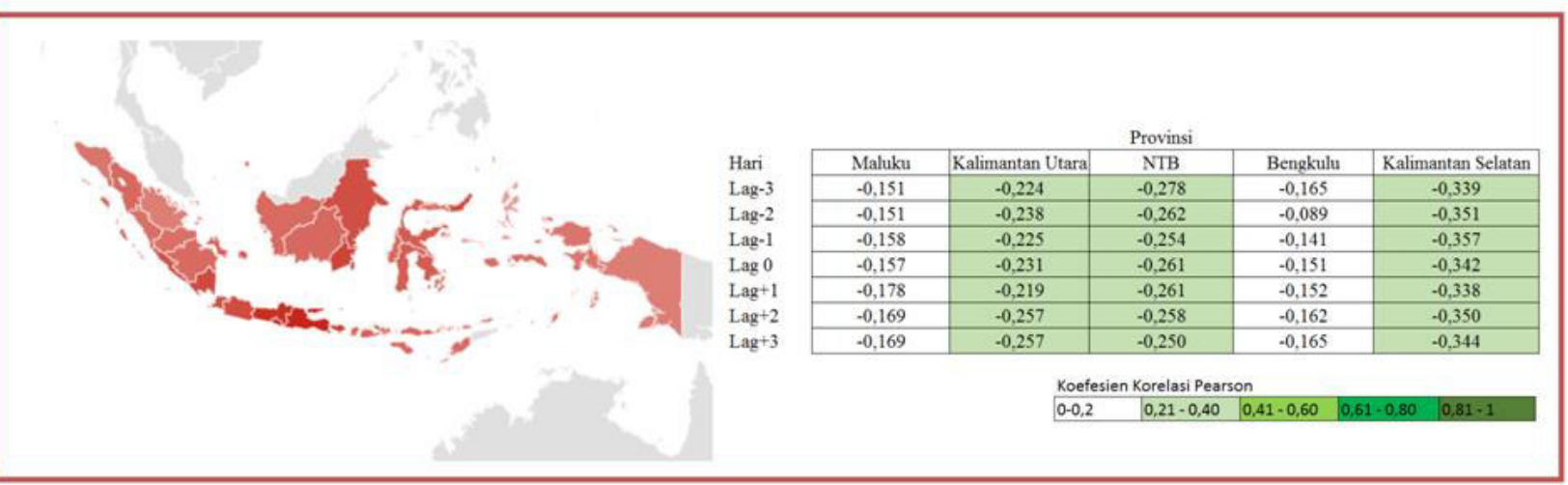

Gambar 2. Hasil korelasi time-lag pearson antara keyword "Masker Kain" dan kasus harian COVID19 pada lima provinsi teratas dengan minat penelusuran tertinggi. 
*Signifikan dengan $\mathrm{P} \leq 0,05$

**Signifikan dengan $\mathrm{P} \leq 0,01$

Dari hasil uji korelasi pearson di atas didapatkan bahwa terdapat dua provinsi dengan korelasi negatif sangat rendah yakni Maluku dan Bengkulu. Hal ini menunjukkan bahwa tiga provinsi tersebut memiliki minat aktivitas googling pada satu hingga tiga hari sebelum, sesudah dan pada hari COVID-19 lebih tinggi dibandingkan dengan tiga provinsi lainnya yakni Kalimantan Utara, NTB dan Kalimantan Selatan.
Hasil korelasi time-lag pearson antara keyword "Masker N-95" dan kasus harian COVID-19 pada lima provinsi teratas dengan minat penelusuran tertinggi ditunjukkan pada Gambar 3. Gradasi warna pada peta menunjukkan tingkat minat, gradasi yang lebih gelap menunjukkan tingkat minat yang lebih tinggi.

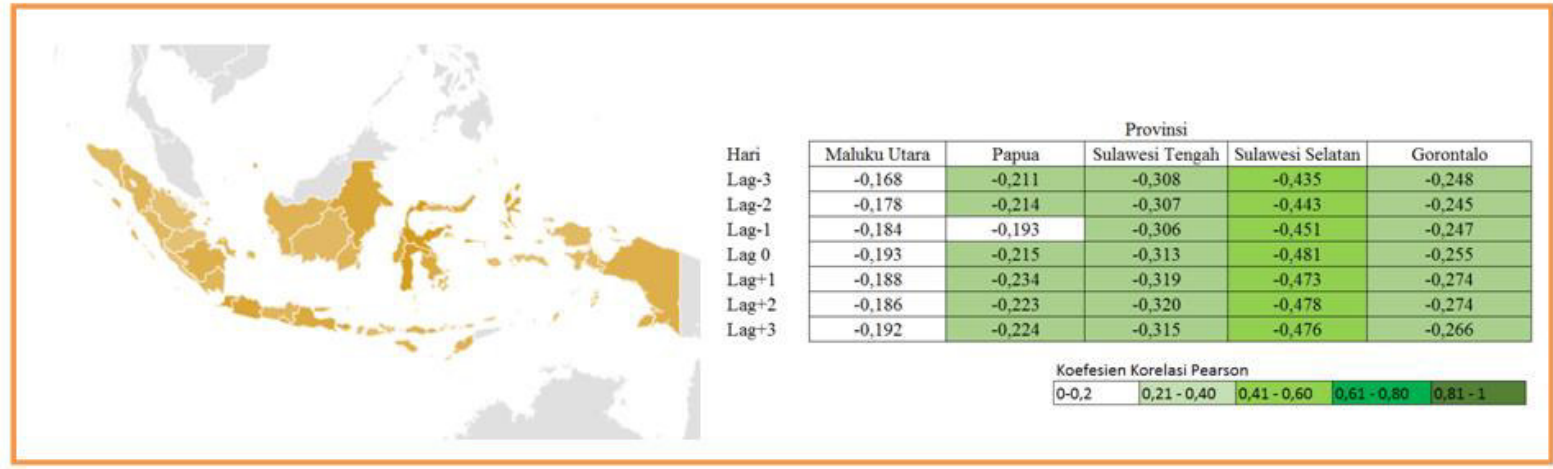

Gambar 3. Hasil korelasi time-lag pearson antara keyword "Masker N-95" dan kasus harian COVID19 pada lima provinsi teratas dengan minat penelusuran tertinggi.

*Signifikan dengan $\mathrm{P} \leq 0,05$

**Signifikan dengan $\mathrm{P} \leq 0,01$

Dari data tersebut dapat terlihat bahwa Maluku memiliki hasil korelasi negatif sangat rendah yang menunjukkan bahwa minat penelurusuran googling tentang "Masker N-95" pada satu hingga tiga hari sebelum, sesudah dan pada saat terjadi COVID-19 sangat tinggi. Namun dapat dilihat data tersebut bahwa sehari sebelum terjadi COVID-19 minat penelusuran googling pada Provinsi Papua sangat tinggi kemudian menurun pada saat terjadi COVID-19 hingga 3 hari kedepannya. Sedangkan Provinsi Sulawesi Selatan adalah provinsi dengan minat penelusuran googling tentang "Masker N-95" terendah pada satu hingga tiga hari sebelum, sesudah dan pada saat terjadi COVID-19 dengan hasil korelasi negatif yang lebih tinggi dari empat provinsi lainnya.

Banyaknya pengguna internet di berbagai lokasi dapat menentukan volume pencarian internet. Secara umum, ada korelasi yang lebih tinggi di wilayah tersebut dengan tingkat penetrasi internet yang lebih tinggi. ${ }^{17}$ Studi lain juga menunjukkan tantangan terkait 
penetrasi internet dan perilaku pencarian informasi dalam implementasi penelitian Google Trends di Indonesia. ${ }^{18}$ Penelitian lain menyatakan bahwa Google Trends lebih cocok untuk digunakan di negara berkembang dengan penetrasi internet yang lebih luas. ${ }^{19}$ Penerapan penggunaan Google Trends di wilayah dengan penetrasi internet rendah masih menjadi tantangan dan perlu validasi penggunaan Google Trends di wilayah dengan prevalensi penyakit tinggi di Indonesia dengan tingkat penetrasi internet sebagai pembanding.

\section{KESIMPULAN}

Berdasarkan data google trends (GT) didapatkan bahwa minat penelusuran masyarakat meningkat pada awal COVID-19 memasuki Indonesia, yang menunjukkan tingkat kepedulian masyarakat terkait COVID19 juga tinggi. Namun, minat pencarian ini terus menurun dan berbanding terbalik dengan meningkatnya angka kejadian kasus COVID19 di Indonesia. Data GT dapat kita gunakan sebagai sumber untuk mengetahui tingkat keminatan masyarakat terhadap sebuah isu atau kasus yang sedang ada, sehingga dengan menggunakan GT kita juga bisa melihat reaksi masyarakat terhadap sebuah topik dengan melihat pola minat pencarian masyarakat terkait topik tersebut, dalam penelitian ini adalah COVID-19.

\section{DAFTAR PUSTAKA}

1. World Health Organization Indonesia. Anjuran Mengenai Penggunaan Masker dalam Konteks COVID-19. 2020. Available from https://www.who.int/docs/defaultsource/searo/indonesia/COVID19/anjuran -mengenai-penggunaan-masker-dalam-

konteks-COVID-19-june-

20.pdf?sfvrsn=d1327a85 2. Accessed on August $31^{\text {st }} 2020$.

2. Long $Y$, Hu T, Liu L, Chen R, Guo Q, Yang $L$, et al. Effectiveness of N95 respirators versus surgical masks against influenza: $A$ systematic review and meta-analysis. J Evid Based Med. 2020;13(2):93-101.

3. Kementerian Kesehatan Republik Indonesia. Begini Aturan Pemakaian Masker Kain yang Benar. 2020. Available from

https://www.kemkes.go.id/article/view/200 60900002/begini-aturan-pemakaianmasker-kain-yang-benar.html. Accessed on September 12rd, 2020

4. Masluha, Siti. Menkes Terawan Tegaskan Masker Hanya Untuk Orang Sakit. Jakarta: detikHealth

5. Supriatna, Iwan. 2020. Pedagang Masker Kain Raup Rp 500 Ribu per Hari. Pariaman: Suara

6. Rosana, F.C. 2020. Masker Diburu, Produsen Pakaian Dalam Jual Seharga Rp 6.000-an. Jakarta: Tempo

7. Tobing, Sorta. 2020. Plus-Minus Masker Kain Menangkal Penularan Virus Corona. Manado: KataData

8. Fadil, Vicky. 2020. Corona Makin Ganas, Indonesia Kirim 10 Ribu Masker N95 ke China. Jakarta: WartaEkonomi.

9. Arifin, Zaenal. 2020. Harga Masker di Pasar Pramuka Melambung. Jakarta: MedCom

10. Fitriyani, Ema. 2020. Ada Pasien Positif Virus Corona, Harga Masker N95 
Melambung Lagi Capai Rp 2 Juta. Jakarta: Kumparan

11. Azzahra, TA. 2020. Harga Masker di Pramuka: N-95 Rp 1,5 Juta, Sensi Rp 340 Ribu. Jakarta: Detik News.

12. Chandra, Michael \& Syakurah, Rizma. (2020). Potential Use of Personal Protection Online Search during COVID19 Pandemic for Predicting and Monitoring Public

Response. 10.13140/RG.2.2.34206.15681.

13. Ermalena, Yosi. 2020. Anjuran Who Mengenai Penggunaan Masker Bagi Masyarakat Yang Akan Keluar Rumah Di Tengah Pandemik Virus Corona (COVID19). Jakarta; Pusat Penyuluhan Sosial.

14. Aida, NR. 2020. Studi: Masker N95 Lebih Unggul Lindungi Petugas Medis dari Virus Corona. Jakarta;Kompas.

15. Septiani, A. 2020. Mengenal Scuba, Jenis Kain yang Lagi Ngetren Jadi Bahan Masker. Jakarta: Detik Health.

16. Widutaputra.2020. Respirator N95 pada Darurat COVID-19. Jakarta; Himpunan Sterilisasi Sentral Indonesia (HISSI).
17. Husnayain, A.; Fuad, A.; Su, ECY. Applications of google search trends for risk communication in infectious disease management: A case study of COVID-19 outbreak in Taiwan. International Journal of Infectious Diseases 2020, 95, p221. 223,

doi:https://doi.org/10.1016/j.ijid.2020.03.0 21.

18. Husnayain, A.; Fuad, A.; Lazuardi, L. Correlation between Google Trends on dengue fever and national surveillance report in Indonesia. Global health action 2019 12 , 1552652.doi: $\underline{10.1080 / 16549716.2018 .15}$ $\underline{52652}$

19. Khafi, K. Indonesia reports highest daily rise in COVID-19 cases for the second time in a week [Internet]. Available from: https://www.thejakartapost.com/news/202 0/05/09/indonesia-reports-highest-dailyrise-in-covid-19-cases-for-second-time-ina-week.html (accessed on 15 May 2020). 